\title{
Baltic Sea diazotrophic cyanobacterium is negatively affected by acidification and warming
}

\author{
Allanah J. Paul ${ }^{1, *}$, Ulrich Sommer ${ }^{1}$, Carolin Paul ${ }^{1,2}$, Ulf Riebesell ${ }^{1}$ \\ ${ }^{1}$ GEOMAR Helmholtz-Centre for Ocean Research Kiel, Düsternbrooker Weg 20, 24105 Kiel, Germany \\ ${ }^{2}$ Leibniz Institute for Baltic Sea Research Warnemünde, Seestraße 15, 18119 Rostock, Germany
}

\begin{abstract}
Nitrogen fixation is a key source of nitrogen in the Baltic Sea which counteracts nitrogen loss processes in the deep anoxic basins. Laboratory and field studies have indicated that single-strain nitrogen-fixing (diazotrophic) cyanobacteria from the Baltic Sea are sensitive to ocean acidification and warming, 2 drivers of marked future change in the marine environment. Here, we enclosed a natural plankton community in 12 indoor mesocosms (volume 1400 l) and manipulated partial pressure of carbon dioxide $\left(p \mathrm{CO}_{2}\right)$ in seawater to yield $6 \mathrm{CO}_{2}$ treatments with 2 different temperature treatments $\left(16.6^{\circ} \mathrm{C}\right.$ and $22.4^{\circ} \mathrm{C}_{,} p \mathrm{CO}_{2}$ range $\left.=360-2030 \mu \mathrm{atm}\right)$. We followed the filamentous, heterocystous diazotrophic cyanobacteria community (Nostocales, primarily Nodularia spumigena) over 4 wk. Our results indicate that heterocystous diazotrophic cyanobacteria may become less competitive in natural plankton communities under ocean acidification. Elevated $\mathrm{CO}_{2}$ had a negative impact on Nodularia sp. biomass, which was exacerbated by warming. Our results imply that Nodularia sp. may contribute less to new nitrogen inputs in the Baltic Sea in the future.
\end{abstract}

KEY WORDS: Cyanobacteria $\cdot$ Environmental change $\cdot$ Baltic Sea $\cdot$ Nitrogen fixation $\cdot$ Nodularia spumigena

\section{INTRODUCTION}

The Baltic Sea is a semi-enclosed water body under high anthropogenic stress because of its large and highly populated catchment area (Sweitzer et al. 1996) and long water residence time of over 30 yr due to low water exchange through the Danish Straits (Döös et al. 2004). Eutrophication caused by increased nutrient loads from agricultural run-off has also been of particular concern in the Baltic Sea over the past few decades. This has increased phytoplankton growth, thereby stimulating oxygen consumption and nitrogen (N) loss processes in the deep anoxic basins, and increasing the phosphate pool available for supporting bloom development of filamentous, diazotrophic ( $\mathrm{N}_{2}$-fixing), and potentially toxic cyanobacteria (Vahtera et al. 2007).

Nodularia spumigena is a filamentous, heterocystous, diazotrophic cyanobacterial species found in

*Corresponding author: apaul@geomar.de the Baltic Sea which commonly blooms during the N-limited summer period. These extensive surface blooms have been reported as common occurrences since the 1970s (Hübel \& Hübel 1974) and form an important annual source of new N. N. spumigena and other diazotrophic cyanobacteria assimilate the residual phosphate present after the spring bloom (Kononen et al. 1996) and fix atmospheric N, thereby supplying the wider plankton community with bioavailable $\mathrm{N}$. This $\mathrm{N}$ input replenishes $\mathrm{N}$ pools which are lost through anammox and denitrification in the anoxic bottom waters (Vahtera et al. 2007) and supports between 20 and $45 \%$ of new production in the Baltic Proper annually (Gustafsson et al. 2013).

Climate change introduces new potential drivers of aquatic ecosystem change: anthropogenic carbon dioxide $\left(\mathrm{CO}_{2}\right)$ emissions not only warm the atmosphere and the oceans but the $\mathrm{CO}_{2}$ also dissolves in the surface waters, thereby reducing seawater $\mathrm{pH}$

(C) The authors 2018. Open Access under Creative Commons by Attribution Licence. Use, distribution and reproduction are unrestricted. Authors and original publication must be credited. 
(Brewer 1997). These changes are termed ocean warming and ocean acidification, respectively. Increases in summer surface temperature of $2-4^{\circ} \mathrm{C}$ (von Storch et al. 2015), concurrent with an average surface ocean pH decrease of up to $0.4 \mathrm{pH}$ units (Schneider et al. 2015), are projected for the Baltic Sea by the year 2100. In some regions of the Baltic Sea such as the Kiel Fjord, short-term and seasonal fluctuations already markedly exceed projected changes (Thomsen et al. 2010). These fluctuations may be exacerbated under ocean acidification (Omstedt et al. 2012). Diazotrophic organisms appear to be sensitive to both ocean acidification (Barcelos e Ramos et al. 2007, Fu et al. 2007, Czerny et al. 2009, Wannicke et al. 2012, Hutchins et al. 2013, 2015, Eichner et al. 2014, Gradoville et al. 2014) and warming (Fu et al. 2014) in laboratory studies. However, the response of diazotrophs in field studies with mixed plankton assemblages has been contradictory, with no response to elevated partial pressure of carbon dioxide $\left(p \mathrm{CO}_{2}\right)$ in seawater observed in studies in the Pacific Ocean (Law et al. 2012, Böttjer et al. 2014) and the Baltic Sea (A. J. Paul et al. 2016) and a positive response observed in the Mediterranean Sea (Rees et al. 2017).

In this mesocosm study, we wanted to stimulate a bloom of N. spumigena and follow (1) the response of diazotroph growth and activity to future ocean acidification and warming scenarios in a natural plankton community and (2) any potential changes in new $\mathrm{N}$ inputs. When using a natural community, important factors such as grazing and resource availability and competition will likely modulate bloom initiation and the response of $N$. spumigena to increasing $\mathrm{CO}_{2}$, in contrast to the physiological response observed in single-strain culture studies. This experimental setup used shallow mesocosms ( 1.5 m deep) with high light availability, similar to the conditions present in surface waters in the Baltic Sea during summer. There, strong stratification, high light availability and high temperatures facilitate the development of extensive blooms of filamentous diazotrophic cyanobacteria. Based on laboratory experiments using N. spumigena (Czerny et al. 2009, Eichner et al. 2014), we expected diazotroph activity and growth to be negatively affected by increased $\mathrm{CO}_{2}$ under phosphate repletion but positively affected by increased temperature (Suikkanen et al. 2013), a controlling factor of diazotrophy in the Baltic Sea (Wasmund 1997). Furthermore, we anticipated that $\mathrm{CO}_{2}$ - or temperature-related changes in diazotroph activity and growth will be visible in plankton community biomass due to potential relief of $\mathrm{N}$-limitation in the plankton community.

\section{MATERIALS AND METHODS}

\section{Experimental set-up and sampling procedures}

This mesocosm study took place using the indoor mesocosm facilities at GEOMAR Helmholtz Centre for Ocean Research Kiel, Germany, between 13 August and 13 September 2013. Four temperaturecontrolled rooms each held 3 mesocosms with a volume of $\sim 1400 \mathrm{l}$ and surface area of $\sim 1.54 \mathrm{~m}^{2}$. We employed an experimental design with 2 temperature treatments $\left(\operatorname{cold}=16.5^{\circ} \mathrm{C}\right.$, warm $\left.=22.5^{\circ} \mathrm{C}\right)$, each containing 6 target $p \mathrm{CO}_{2}$ treatments ranging from ambient ( 400 $\mu \mathrm{atm})$ up to $2500 \mu \mathrm{atm}$. The temperature in the warm and cold treatments was increased and decreased by $3^{\circ} \mathrm{C}$, respectively, from ambient temperature of the Kiel Fjord during mesocosm filling to exclude the effect of any potential temperature shock. The 12 mesocosms were filled simultaneously on 13 August $(t-3=3$ d before the onset of the experiment, see also Table S1 in the Supplement at www. int-res.com/articles/suppl/m589p049_supp.pdf) with unfiltered seawater from the Kiel Fjord collected from approximately $2 \mathrm{~m}$ water depth. This water contained a natural summer plankton community from the western Baltic Sea including bacteria, phytoplankton and protozoa. To encourage formation of a filamentous diazotrophic cyanobacterial bloom, 1.751 of Nodularia spumigena culture (strain: SCCAP K-1536) was added to each mesocosm on 14 August $2013(t-2)$. This resulted in an initial cell density of approximately 5100 cells $\mathrm{l}^{-1}$ in each mesocosm. Before addition to the mesocosms, the Nodularia sp. culture was cultivated under temperature and light control $\left(18^{\circ} \mathrm{C}, 150 \mu \mathrm{mol}\right.$ photons $\left.\mathrm{m}^{-2} \mathrm{~s}^{-1}\right)$ in sterile filtered $(0.2 \mu \mathrm{m})$ Kiel Fjord water with $\mathrm{f} / 2$ nutrients, vitamins and trace elements. Mesozooplankton (90\% copepods, mixed species and stages) collected from the Kiel Bight from vertical net catches (10 m depth) were also added to the mesocosms on $t-1$ at a density of 20 ind. $1^{-1}$, simulating levels reported for this region in the summer season (Behrends 1997) to replenish those lost during mesocosm filling. To acclimate the mesozooplankton to the temperature treatments, collected mesozooplankton were kept in $10 \mathrm{l}$ containers for $24 \mathrm{~h}$ in the temperature-controlled rooms. This also enabled dead individuals to be removed before addition to the mesocosms.

A light-permeable polyvinylchloride (PVC) cover on each mesocosm maintained a headspace above the water surface to reduce outgassing of $\mathrm{CO}_{2}$ during the experiment. An electrical propeller gently mixed the water in each mesocosm and ensured 
homogenous distribution of particulate matter and reduced sedimentation. The light intensity and period reflected natural conditions for this latitude and season as calculated by the astronomic model of Brock (1981). The 5 spotlights (HIBay-LED, $100 \mathrm{~W}$ each, Lamp unit HL3700 and Profilux II, wavelength range: $400-800 \mathrm{~nm}$ ) were computer controlled (GHL Groß Hard- und Softwarelösungen). The light:dark cycle of 14.05:9.95 $\mathrm{h}$ included a sunrise/sundown simulation of approximately $2 \mathrm{~h}$ and an average maximum light intensity of $382.7 \mu \mathrm{mol}$ photons $\mathrm{m}^{-2}$ $\mathrm{s}^{-1}$ around noon. Light intensity was measured using a LICOR Li-250A light meter. The experimental time line and a diagram of the mesocosm set-up are provided in Table S1 and Figs. S1 \& S2. Regular sampling from all mesocosms took place every Monday, Wednesday and Friday between $t-2$ (Wednesday, 14 August 2013) and t28 (Friday, 13 September 2013) between 07:00 and 09:30 h local time. Samples for dissolved inorganic carbon (DIC) were taken directly from the centre of the mesocosms at approximately $0.5 \mathrm{~m}$ depth using flexible silicon tubing. Samples for total alkalinity (TA) were collected on the previous evening so that up-to-date TA concentrations could be determined overnight and used on the following sampling day to calculate the required $\mathrm{CO}_{2}$ enrichments. TA fluctuations over the $48-72 \mathrm{~h}$ sampling periods were small and thus the difference in sampling timing to DIC samples had minimal influence on calculation of the $\mathrm{CO}_{2}$ system. Dissolved organic matter was also sampled directly from the mesocosms using a membrane pump and acid-rinsed tubing to minimise the risk of contamination. Water for all other variables (e.g. particulate matter, dissolved inorganic nutrients) was collected into plastic carboys for subsequent sub-sampling.

\section{Carbonate system manipulations}

A range of $\mathrm{CO}_{2}$ treatments was attained by the addition of $\mathrm{CO}_{2}$-saturated seawater. Different amounts of $\mathrm{CO}_{2}$-enriched seawater were added to each treatment to set up a range of $\sim 420-1670 \mu \mathrm{atm}$ average $p \mathrm{CO}_{2}$ in the warm treatment and $~ 365-1920 \mu \mathrm{atm}$ average $p \mathrm{CO}_{2}$ in the cold treatments (see Table $\mathrm{S} 2$ for a summary of total amounts added). $\mathrm{CO}_{2}$ enrichment started on $t-2$ after sampling and took place every sampling day after general sampling until $t 10$. Thereafter, $\mathrm{CO}_{2}$-enriched seawater was added every day, apart from $t 16$ and $t 23$, to maintain more stable $\mathrm{CO}_{2}$ treatments. Seawater for the $\mathrm{CO}_{2}$ enrichments for the whole experiment was collected at the beginning of the study when the mesocosms were being filled, sterile filtered $(0.2 \mu \mathrm{m})$ and stored at $15^{\circ} \mathrm{C}$. Water was bubbled with $\mathrm{CO}_{2}$ gas for at least $6 \mathrm{~h}$ on the day of addition. Nutrient concentrations were determined (see 'Analytical procedures' below) on the day of collection as well as on the last day of $\mathrm{CO}_{2}$ enrichment ( $t 26)$.

\section{Analytical procedures}

$$
\text { Carbonate chemistry (TA, DIC) }
$$

Samples for TA and DIC concentrations were taken directly from the centre of each mesocosm and gently pressure-filtered (Sarstedt Filtropur PES $0.2 \mu \mathrm{m}$ ) to exclude particulate material before analysis. DIC samples were collected as gas samples into $50 \mathrm{ml}$ glass flasks (Schott Duran) with at least $100 \mathrm{ml}$ of overflow. TA was analysed by potentiometric titration on an autosampler (Metrohm 869 Sample Changer) and a 907 Titrando Dosing unit according to the open cell method described by Dickson et al. (2007). DIC was analysed by infrared detection of $\mathrm{CO}_{2}$ by a LICOR LI-7000 on an AIRICA system (MARIANDA). Reported values were calculated as the mean of the 3 best out of 4 measurements with typical precision of $1.5 \mu \mathrm{mol} \mathrm{kg}{ }^{-1}$. Certified reference material provided by Andrew Dickson (CRM 115, Scripps Institute for Oceanography of the University of California, San Diego, USA) was used to correct for any drift during analyses for both TA and DIC between sampling days and within a run. Carbonate system parameters and $p \mathrm{CO}_{2}$ were calculated using measured DIC and TA and the carbonic acid dissociation constants of Millero et al. (2006) in the CO2SYS program (Pierrot et al. 2011), taking into account measured nutrient concentrations, temperature and salinity.

\section{Dissolved inorganic and organic matter}

Dissolved inorganic nitrogen (DIN $=\mathrm{NO}_{3}{ }^{-}+\mathrm{NO}_{2}{ }^{-}$), phosphate (DIP) and ammonium $\left(\mathrm{NH}_{4}{ }^{+}\right)$were filtered (cellulose acetate, $0.8 \mu \mathrm{m}$ pore size, Sartorius Stedim) and frozen at $-20^{\circ} \mathrm{C}$ until analysis. Concentrations were determined on an auto-analyser (Skalar, SAN $^{\text {PLUS }}$ ) as described by Hansen \& Koroleff (1999). The actual detection limit varied between sampling days but was on average $0.57,0.09$ and $0.34 \mu \mathrm{mol} \mathrm{l}^{-1}$ for DIN, DIP and $\mathrm{NH}_{4}{ }^{+}$, respectively. Phosphate 
excess ( $\mathrm{P}^{*}$, Deutsch et al. 2007) was calculated from DIP, DIN and $\mathrm{NH}_{4}{ }^{+}$concentrations according to:

$$
\mathrm{P}^{*}=[\mathrm{DIP}]-\left([\mathrm{DIN}]+\left[\mathrm{NH}_{4}{ }^{+}\right]\right) / 16
$$

For dissolved organic nitrogen and phosphorus (DON and DOP, respectively) analyses, $60 \mathrm{ml}$ of samples were filtered through pre-combusted, acidrinsed GF/F filters $\left(450^{\circ} \mathrm{C}, 6 \mathrm{~h}\right)$ and collected in acidrinsed, high-density polyethylene (HDPE) bottles and stored at $-20^{\circ} \mathrm{C}$ until analyses. Total dissolved nitrogen and phosphorus were converted to inorganic nitrogen and phosphorus using an autoclave (20 min) and alkaline persulfate oxidation. Concentrations were then determined colorimetrically as described by Hansen \& Koroleff (1999). DON concentrations were calculated from total dissolved nitrogen by subtracting DIN and $\mathrm{NH}_{4}{ }^{+}$concentrations. DOP concentrations were calculated from total dissolved phosphate by subtracting DIP concentrations.

\section{Particulate matter $(\mathrm{C}, \mathrm{N}, \mathrm{P})$}

Particulate matter for $\mathrm{C} / \mathrm{N}$ and $\mathrm{P}$ analyses was collected on GF/F filters (Whatman, nominal pore size of $0.7 \mu \mathrm{m}$, diameter $25 \mathrm{~mm}$ ) by filtration under reduced vacuum $(<200$ mbar) between $t 1$ and $t 28$. Filtration volumes ranged between 100 and $250 \mathrm{ml}$ to ensure sufficient biomass on the filters for analysis. Samples for analysis by mass spectrometry were stored at $-20^{\circ} \mathrm{C}$ until analysis before they were dried overnight at $60^{\circ} \mathrm{C}$ and packed into tin capsules. Particulate nitrogen and carbon were converted to $\mathrm{N}_{2}$ and $\mathrm{CO}_{2}$ gas, respectively, using the method of Sharp (1974), and the stable isotope ratio $\left({ }^{15} \mathrm{~N} /{ }^{14} \mathrm{~N}\right)$ was analysed on a Finnigan Delta ${ }^{\text {Plus }}$ isotope ratio mass spectrometer coupled by a Conflo II to an elemental analyser (EuroEA). In addition to the standard calibration at the beginning of each run, standard materials (caffeine, peptone and acetanilide) were also included within runs to identify any drift and ensure accuracy and full combustion of the samples during analysis. Natural abundance isotope ratios in particulate $\mathrm{N}\left(\delta^{15} \mathrm{~N}-\mathrm{PN}\right)$ are reported in per mil (\%) compared to the atmospheric $\mathrm{N}_{2}$ standard (AIR). Due to analytical problems (SD $>0.2 \%$ in standard material $\delta^{15} \mathrm{~N}$ ) with the samples on $t 1$ (biomass too low) and t28 (problems with calibration), these data points were excluded from analyses. Total particulate phosphorus concentrations were determined spectrophotometrically as described by Hansen \& Koroleff (1999).
Phytoplankton biomass

Phytoplankton abundances for organisms $>5 \mu \mathrm{m}$ were determined to the species level and counted using an inverted light microscope in Lugol-fixed samples (Utermöhl 1958) using $50 \mathrm{ml}$ sedimentation chambers. Common species were counted in diametrical strips using $20 \times, 40 \times$ and $60 \times$ lens magnification, depending on cell size. Large and rare species (including Nodularia) were counted by scanning the entire bottom plate with a $10 \times$ lens. The uppermost volume of the chambers was examined for floating cyanobacterial colonies, which were never found.

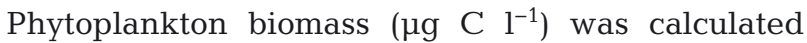
from abundances using geometric standards (Hillebrand et al. 1999) and carbon content as described by Menden-Deuer \& Lessard (2000). Flow cytometry abundances for organisms $<5 \mu \mathrm{m}$ were converted to carbon content using the factors of Sommer et al. (2012). Total phytoplankton biomass was calculated as the combination of phytoplankton carbon content from flow cytometry $(<5 \mu \mathrm{m})$ and microscope $(>5 \mu \mathrm{m})$ estimations. Nostocales biomass is the combined biomass of $N$. spumigena and Dolichospermum sp., the 2 most abundant filamentous diazotrophic cyanobacteria observed in this study.

\section{Statistical analyses}

We tested the effects of temperature and measured $p \mathrm{CO}_{2}$ on diazotroph biomass (Nostocales) and indicators of diazotroph activity $\left(\delta^{15} \mathrm{~N}-\mathrm{PN}, \mathrm{P}^{*}, \mathrm{DOP}\right)$ by building non-linear mixed-effects (NLME) models using the R package nlme (Pinheiro et al. 2015). The experiment was divided into a bloom $(t 0-t 10)$ and a post-bloom phase $(t 12-t 28)$. We defined this as the phase when phytoplankton biomass was in decline

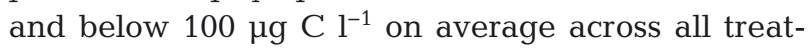
ments (see also Fig. 3). An NLME model was chosen for this particular analysis because the longitudinal data set included repeated measures, potentially nonconstant correlation between observations and nonlinear variable response (Lindstrom \& Bates 1990).

Nostocales biomass was not normally distributed, so data were log-transformed to satisfy the assumption of normality in the model residuals. We used $p \mathrm{CO}_{2}$ and temperature as fixed effects to test their influence on diazotroph biomass in the first model $\left(p \mathrm{CO}_{2} \times\right.$ temperature). We then tested the effect of diazotroph biomass, $\mathrm{CO}_{2}$ and temperature on key biogeochemical indicators $\left(\delta^{15} \mathrm{~N}-\mathrm{PN}, \mathrm{P}^{*}, \mathrm{DOP}\right)$ using the model Nostocales biomass $\times p \mathrm{CO}_{2} \times$ temperature. In 
both models, mesocosm was included as a random effect. We simplified the models to exclude all nonsignificant terms $(p>0.05)$. Normality of residuals and heteroscedasticity were inspected visually and satisfied model assumptions before performing an ANOVA to test significance of each variable. No collinearity was detected between $p \mathrm{CO}_{2}$ and Nostocales biomass.

\section{RESULTS}

\section{Carbonate system and environmental variables}

Temperature treatment levels of $22.4 \pm 0.1^{\circ} \mathrm{C}$ (warm) and $16.6 \pm 0.4^{\circ} \mathrm{C}$ (cold) were reached (mean \pm $\mathrm{SD})$ by $t 2$ and remained within $0.4^{\circ} \mathrm{C}$ of these values until the end of the experiment on $t 28$. A gradient of $\mathrm{CO}_{2}$ treatments was present from $t 3$ onwards, with average $p \mathrm{CO}_{2}$ ranging from 420 to $1760 \mu$ atm in the warm treatment, and from 360 to $2030 \mu$ atm in the cold treatment (Fig. 1A,B). However, there was a high level of variability within each treatment, particularly in the highest $p \mathrm{CO}_{2}$ treatments primarily due to the high concentration difference to the atmospheric level and corresponding high level of outgassing in the shallow mesocosms. Daily additions of $\mathrm{CO}_{2}$-enriched seawater after $t 10$ (except for $t 16$ and t23) improved stability within each treatment.

Salinity ranged between 15.2 and 15.3, and TA remained relatively stable and ranged between 1950 and $1970 \mu \mathrm{mol} \mathrm{kg}{ }^{-1}$. There was a small TA drawdown later in the study period during the post-bloom phase (Fig. 1C,D). This appeared to be slightly higher at lower $\mathrm{CO}_{2}$ and higher temperature.

\section{Filamentous diazotrophic cyanobacterial biomass and contribution to phytoplankton community biomass}

Nodularia spumigena was the dominant filamentous diazotrophic cyanobacterium identified in all mesocosms. Biomass increased with additions of $N$. spumigena culture to all mesocosms with an average biomass on $t 0$ of $0.62 \pm 0.09$ and $0.62 \pm 0.11 \mu \mathrm{g} \mathrm{C}$ $\mathrm{l}^{-1}$ (mean $\pm \mathrm{SD}$ ) in the warm and cold treatments, respectively (Fig. 2A,B). The next dominant species identified in the order Nostocales was Dolichospermum sp., which contributed on average to less than $15 \%$ of Nostocales biomass (N. spumigena $=0.32 \pm$ $0.32 \mu \mathrm{g} \mathrm{Cl}^{-1}$, Dolichospermum $=0.05 \pm 0.10 \mu \mathrm{g} \mathrm{Cl}^{-1}$, mean $\pm \mathrm{SD}$ ), but up to $100 \%$ of biomass in some warm treatments during the post-bloom phase when $N$. spumigena was no longer present.

Total phytoplankton biomass declined during the experiment and remained low $\left(89.7 \pm 66.7 \mu \mathrm{g} \mathrm{Cl^{-1 }}\right.$, mean $\pm \mathrm{SD}$; Fig. $3 \mathrm{~A}, \mathrm{~B})$ and within the range of reported values for the Kiel Fjord (Wasmund et al. 2008). There was a higher variability in starting phytoplankton community biomass on $t-2$ between mesocosms in the cold treatment $(157.6 \pm 49.5 \mu \mathrm{g} \mathrm{C}$ $\left.\mathrm{l}^{-1}\right)$ than in the warm treatment $\left(168.3 \pm 13.1 \mathrm{\mu g} \mathrm{C}^{-1}\right)$. Nostocales biomass declined over time, and the max-

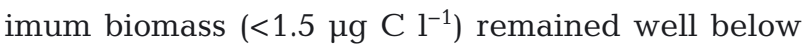
the definition of a bloom of $22 \mu \mathrm{g} \mathrm{C}^{-1}$ according to Wasmund (1997). The observed biomass was also considerably lower than other studies with artificial blooms ( 460 $\mu \mathrm{g} \mathrm{C} \mathrm{l}^{-1}$, Engström-Öst et al. 2002) and contributed on average to less than $3 \%$ of total phytoplankton biomass throughout the study period. In some cold treatment mesocosms, the contribution of Nostocales to phytoplankton community biomass increased after $t 20$ to up to $23 \%$ (Fig. 2C,D).

No direct effect of temperature was detected, but there was a significant effect of $\mathrm{CO}_{2}$ on Nostocales biomass in both the bloom and post-bloom periods and in both temperature treatments. A highly significant interactive effect between $\mathrm{CO}_{2}$ and temperature was detected ( $p<0.0001$, Table 1). Nostocales biomass was generally highest under low $\mathrm{CO}_{2}$ and low temperature and lowest under high $\mathrm{CO}_{2}$ and high temperature (Fig. 2). An increase in Nostocales biomass after the $N$. spumigena culture addition on t0 was only discernible in the lowest $\mathrm{CO}_{2}$ treatments.

\section{Indicators of diazotrophic activity}

While $\mathrm{N}_{2}$-fixation rates were analysed following a method with minor modifications from Mohr et al. (2010), ${ }^{15} \mathrm{~N}-\mathrm{N}_{2}$ gas contaminated with ${ }^{15} \mathrm{~N}$-labelled ammonium, nitrate and/or nitrite was used (Dabundo et al. 2014) and thus the measured rates are considered unreliable for this study. Nevertheless, we analysed $\delta^{15} \mathrm{~N}-\mathrm{PN}, \mathrm{DOP}$ and $\mathrm{P}^{*}$ as indicators of diazotrophic activity as described in the following 2 sections.

Stable isotope ratios in particulate nitrogen

$\delta^{15} \mathrm{~N}-\mathrm{PN}$ decreased from $3.5 \pm 1.2 \%$ (mean $\pm \mathrm{SD}$ ) on $t 3$ to reach a minimum of $-0.2 \pm 1.2 \%$ on $t 10$ before increasing again in the post-bloom period to reach $2.2 \pm 1.7 \%$ on $t 26$ across all $\mathrm{CO}_{2}$ and temperature treatments (Fig. 2E,F). There was a significant 

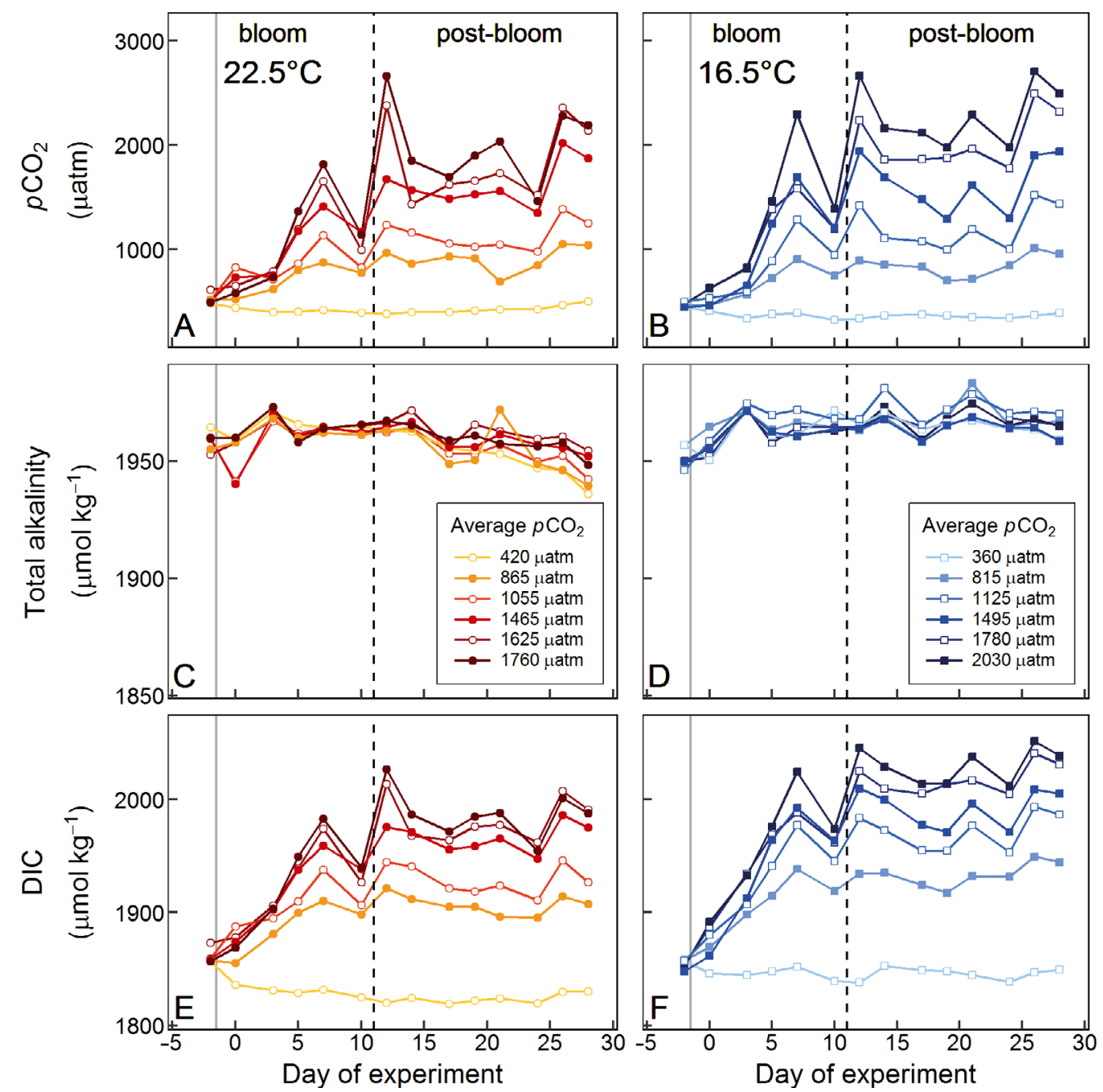

Fig. 1. Carbonate system variables during the study period. Calculated $p \mathrm{CO}_{2}$, measured total alkalinity and dissolved inorganic carbon (DIC). Grey vertical lines indicate when the Nodularia spumigena culture was added to the mesocosms, and the black dashed vertical lines indicate the division between bloom and post-bloom phases

negative effect of temperature on $\delta^{15} \mathrm{~N}-\mathrm{PN}$ in both the bloom and post-bloom periods $(\mathrm{p}=0.0054$ and $\mathrm{p}=$ 0.0008 , respectively; Table 2), but no significant effect of $\mathrm{CO}_{2}$. In the post-bloom period, there was a significant interaction between $\mathrm{CO}_{2}$ and Nostocales biomass on $\delta^{15} \mathrm{~N}-\mathrm{PN}(\mathrm{p}<0.0001$, Table 2$)$, even though there was no significant effect of either factor independently.

\section{Inorganic and organic nutrient concentrations}

Nutrient concentrations directly after mesocosms were filled on $t-3$ were $0.60,1.83$ and $0.66 \mu \mathrm{mol} \mathrm{l}^{-1}$ for DIN, $\mathrm{NH}_{4}{ }^{+}$and DIP, respectively. DIN and $\mathrm{NH}_{4}{ }^{+}$ concentrations in almost all samples were below the detection limits, which were on average 0.60 and $0.34 \mu \mathrm{mol} \mathrm{l}^{-1}$, respectively, as is common for the summer season in the Kiel Fjord (Smetacek 1985). There was an excess of inorganic phosphate $\left(\mathrm{P}^{*}\right)$ in all mesocosms throughout the study period (Fig. 3C,D; $0.33 \pm 0.10 \mu \mathrm{mol} \mathrm{l}^{-1}$, mean $\pm \mathrm{SD}$ ), compared to inorganic $\mathrm{N}$ according to the Redfield ratio (Redfield 1958). During the bloom phase, Nostocales biomass, $p \mathrm{CO}_{2}$ and temperature all had a significant negative effect on $\mathrm{P}^{*}$ (Table 2), whereas in the post-bloom period, only temperature still had a significant negative effect $(p<0.0001)$. In addition, there was a positive interactive effect of Nostocales biomass and temperature on $\mathrm{P}^{*}$ during the post-bloom phase.

Through the regular additions of $\mathrm{CO}_{2}$-enriched seawater to maintain more constant $p \mathrm{CO}_{2}$ in the 

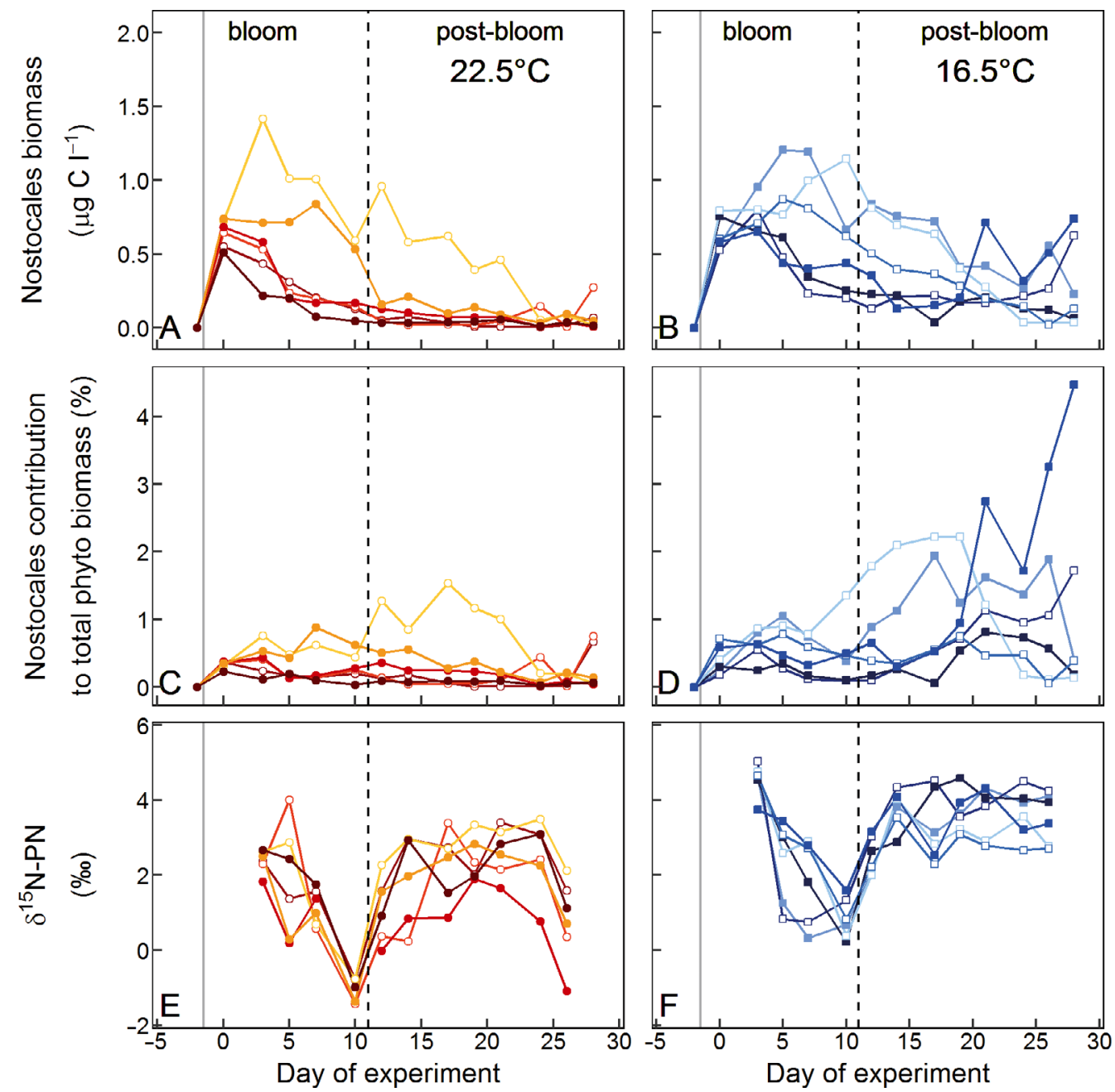

Fig. 2. (A,B) Development of filamentous diazotrophic cyanobacterial biomass (order Nostocales), calculated from microscopy counts of Nodularia spumigena and Dolichospermum sp. using reported biovolumes (Olenina et al. 2006) and cellular carbon content (Menden-Deuer \& Lessard 2000), and (C,D) \% contribution to phytoplankton community biomass. (E,F) $\delta^{15} \mathrm{~N}-\mathrm{PN}(\%)$ is reported as potential indicator of diazotroph activity during the study period. Colours, symbols and lines are as described in Fig. 1

mesocosms, we also inadvertently added small amounts of inorganic nutrients $\left(\mathrm{NH}_{4}{ }^{+}\right.$, DIN and DIP). However, total amounts added during the study period were small $\left(0.02 \mu \mathrm{mol} \mathrm{l} \mathrm{l}^{-1}\right.$ DIN, $0.02 \mu \mathrm{mol} \mathrm{l^{-1 }}$ DIP, $0.07 \mu \mathrm{mol} \mathrm{l}^{-1} \mathrm{NH}_{4}{ }^{+}$) and remained well below the ambient $\mathrm{N}$ pool size (e.g. DON $\sim 17 \mu \mathrm{mol} \mathrm{l}^{-1}$, PON $\sim 2 \mu \mathrm{mol} \mathrm{l}^{-1}$ ) in the mesocosms. We consider the minor nutrient input during $\mathrm{CO}_{2}$ manipulations to have had a negligible effect on Nostocales biomass with negligible relief of N-limitation of the phytoplankton present. Amounts of added $\mathrm{NH}_{4}{ }^{+}$were not of a magnitude shown to affect $N$. spumigena growth or activity (Huber 1986, Sanz-Alférez \& del Campo 1994, Lehtimaki et al. 1997, Vintila \& El-Shehawy 2010).

DOP concentrations in the mesocosms were on

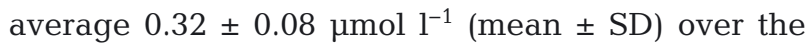

entire study period, and there was no significant effect of Nostocales biomass, $p \mathrm{CO}_{2}$ or temperature (data not shown).

\section{DISCUSSION}

\section{Influence of elevated seawater $\mathrm{CO}_{2}$ and temperature on diazotroph abundances}

Rising seawater $\mathrm{CO}_{2}$ led to lower biomass of filamentous diazotrophic cyanobacteria, predominantly Nodularia spumigena and Dolichospermum sp., with excess phosphate present. Thus, this study using a natural Baltic Sea plankton community agrees with the results of 2 monoculture studies which reported 

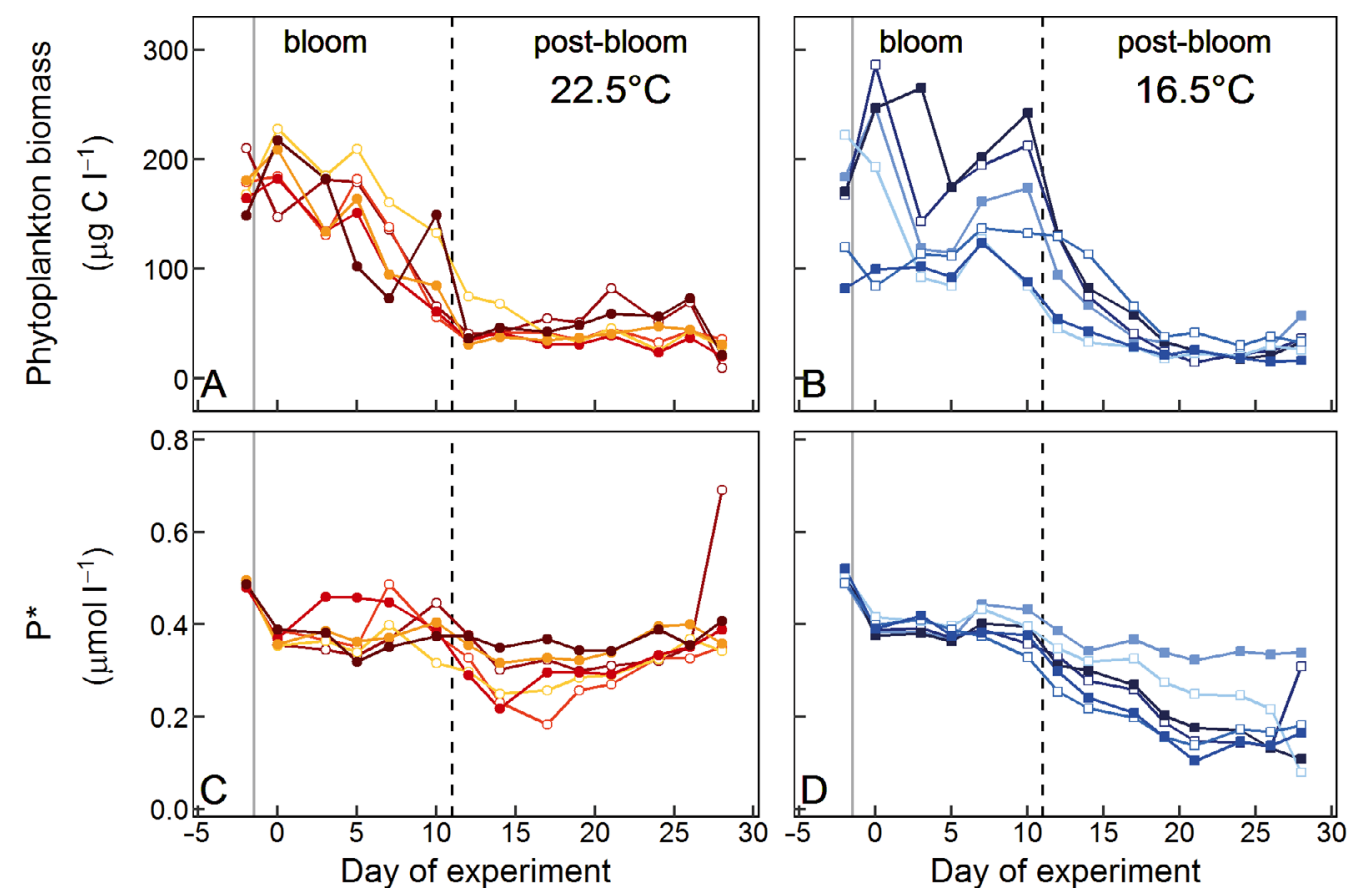

Fig. 3. Phytoplankton community biomass, calculated from microscopy of phytoplankton abundances using reported biovolumes (Olenina et al. 2006) and cellular carbon content (Menden-Deuer \& Lessard 2000), and excess dissolved inorganic phosphate $\left(\mathrm{P}^{*}\right)$ dynamics during the study period. Colours, symbols and lines are as described in Fig. 1

Table 1. Summary of detected significant fixed effects in mixed effects model analyses for diazotroph biomass (Nostocales). The initial model tested $\left(p \mathrm{CO}_{2} \times\right.$ temperature) was simplified to remove all insignificant fixed effects. Bloom and post-bloom indicate $t-2$ (i.e. $2 \mathrm{~d}$ before onset of the experiment) to $t 10$ ( $10 \mathrm{~d}$ after), and $t 12$ to $t 28$, respectively. Nostocales was log-transformed to satisfy the assumption of normally distributed residuals in the simplified model. Values indicate $F$-statistics. Arrows indicate direction of the response, with ${ }^{* *} p<0.01$ and ${ }^{* * *} p>0.001$

\begin{tabular}{|lcc|}
\hline $\begin{array}{l}\text { Significant } \\
\text { fixed effect }\end{array}$ & \multicolumn{2}{l|}{$\log ($ Nostocales biomass) } \\
& $\begin{array}{c}\text { Bloom } \\
(\mathrm{df}=46)\end{array}$ & $\begin{array}{c}\text { Post-bloom } \\
(\mathrm{df}=82)\end{array}$ \\
\hline$p \mathrm{CO}_{2}$ & $39.24^{* * *} \downarrow$ & $9.56^{* *} \downarrow$ \\
$p \mathrm{CO}_{2} \times$ temperature & $23.52^{* * *} \downarrow$ & $57.04^{* * *} \downarrow$ \\
\hline
\end{tabular}

lower growth rates in $N$. spumigena with rising $\mathrm{CO}_{2}$ (Czerny et al. 2009, Eichner et al. 2014). The small artificial $N$. spumigena bloom was sustained for longer in the lowest $\mathrm{CO}_{2}$ treatments in both temperature treatments. An increase in observed biomass indicates net growth in these treatments during the bloom phase (Fig. 2A,B). In contrast, there was no clear period of biomass accumulation or bloom development in any $\mathrm{CO}_{2}$ treatment above 1000 ratm (average treatment $p \mathrm{CO}_{2}$ ) in the warm treatment.
The $\mathrm{CO}_{2}$ treatment levels selected here of up to an average of $\sim 2000 \mu$ atm spanned a much wider range than the widely recognised projections by 2100 of up to 1000 patm (Collins et al. 2013) but are within the natural range of the Kiel Fjord which can reach up to $3000 \mu$ atm during late summer (Thomsen et al. 2010). Nevertheless, the strongest biomass response to $p \mathrm{CO}_{2}$ appeared to be between ambient and approximately $1000 \mu \mathrm{atm}$. This indicates a potential $p \mathrm{CO}_{2}$ threshold for net Nostocales growth. Similarly, the most marked changes in diazotroph activity and growth in a variety of oceanic taxa were evident within a comparable, and ocean acidification-relevant, $p \mathrm{CO}_{2}$ range (Hutchins et al. 2013). Based on both our study and results from Hutchins et al. (2013), we suggest that the most critical changes in diazotroph physiology may occur within the range of realistic future average $p \mathrm{CO}_{2}$ levels (under $1000 \mu \mathrm{atm})$.

Rising temperature has been proposed as a key driver of the observed increased filamentous cyanobacterial presence in summer in the Baltic Sea (Suikkanen et al. 2013), with suggestions that future warming will continue this positive trend (HELCOM 2013). Warmer temperatures promote growth in slow-growing diazotrophs, increasing their competitiveness with other autotrophic organisms in plank- 
Table 2. Summary of detected significant fixed effects in mixed effects model analyses of and indirect indicators of diazotroph activity $\left(\delta^{15} \mathrm{~N}\right.$ in particulate nitrogen $\left[\delta^{15} \mathrm{~N}-\mathrm{PN}\right]$ and excess dissolved inorganic phosphate concentration $\left[\mathrm{P}^{*}\right]$ ). The initial model tested (Nostocales biomass $\times p \mathrm{CO}_{2} \times$ temperature) was simplified to remove all insignificant fixed effects. Bloom and post-bloom indicate $t-2$ to $t 10$ and $t 12$ to $t 28$, respectively. Values indicate $F$-statistics, and dashes (-) indicate that the fixed effect had no significant effect on the variable. Arrows indicate direction of the response, with ${ }^{* *} p<0.01,{ }^{* * *} p>0.001$

\begin{tabular}{|c|c|c|c|c|}
\hline \multirow{2}{*}{$\begin{array}{l}\text { Significant } \\
\text { fixed effect }\end{array}$} & \multicolumn{2}{|c|}{$\delta^{15} \mathrm{~N}-\mathrm{PN}$} & \multicolumn{2}{|c|}{$-\left[\mathrm{P}^{*}\right]$} \\
\hline & $\begin{array}{l}\text { Bloom } \\
(\mathrm{df}=35)\end{array}$ & $\begin{array}{l}\text { Post-bloom } \\
\quad(\mathrm{df}=69)\end{array}$ & $\begin{array}{l}\text { Bloom } \\
(\mathrm{df}=55)\end{array}$ & $\begin{array}{l}\text { Post-bloom } \\
(\mathrm{df}=81)\end{array}$ \\
\hline Nostocales biomass & & - & $23.70^{* * *} \downarrow$ & - \\
\hline$p \mathrm{CO}_{2}$ & & - & $20.89^{* * *} \downarrow$ & \\
\hline Temperature & $8.81^{* *} \downarrow$ & $12.24^{* * *} \downarrow$ & $8.79^{* *} \downarrow$ & $19.61^{* * *} \downarrow$ \\
\hline $\begin{array}{l}\text { Nostocales biomass } \times \\
\quad p \mathrm{CO}_{2}\end{array}$ & & $16.50^{* * *} \downarrow$ & & \\
\hline $\begin{array}{l}\text { Nostocales biomass } \times \\
\text { temperature }\end{array}$ & & & & $7.30^{* *} \uparrow$ \\
\hline
\end{tabular}

nance of $\mathrm{CO}_{2}$ treatments, and hence maintenance of treatment stress, may have contributed to the comparatively strong $\mathrm{CO}_{2}$ response in diazotroph biomass in this study. However, we would be careful to extrapolate this lack of temperature effect on Nostocales growth that we observed outside the framework of this specific experimental set-up. In particular, there is substantial evidence and widespread agreement in the literature on the critical role of temperature on growth of filamentous diazotrophic cyanobacteria (Staal et al. 2003, Breitbarth et al. 2007, Paerl \& Huisman 2008), including in the Baltic Sea (Wasmund 1997, Suikkanen et al. 2013). ton communities (Paerl 2012) and thereby stimulate blooms of $N$. spumigena in the field (Kononen et al. 1996, Pliński \& Jóźwiak 1999). However, we could not identify any direct relationship between temperature and Nostocales biomass, in either the bloom or post-bloom phases (Table 1), even though the warm temperature treatment $\left(22.4^{\circ} \mathrm{C}\right)$ was within the reported optimum temperature range of $20-25^{\circ} \mathrm{C}$ for N. spumigena growth (Lehtimaki et al. 1994). The only significant temperature effect observed was an interactive effect between temperature and $\mathrm{CO}_{2}$ concentrations: the negative effect of increasing $\mathrm{CO}_{2}$ on Nostocales biomass was exacerbated at higher temperatures in both the bloom and post-bloom phases.

Temperature is generally considered to have a more marked impact on plankton growth than seawater $p \mathrm{CO}_{2}$ based on studies on plankton community responses (Hare et al. 2007, Coello-Camba et al. 2014, Maugendre et al. 2015, Sommer et al. 2015), growth parameters in single strain culture experiments in the laboratory (Fu et al. 2007) and using structural equation modelling (Alsterberg et al. 2013). Indeed, the response of Nostocales to elevated $\mathrm{CO}_{2}$ but not elevated temperature that we observed here is contrary to the response of the wider plankton community in this experiment (C. Paul et al. 2016). This may be due, at least in part, to the experimental design used in this study. Unlike previous mesocosm experiments, where $p \mathrm{CO}_{2}$ has fluctuated with the plankton bloom dynamics (Engel et al. 2008, Schulz et al. 2013), almost daily additions of $\mathrm{CO}_{2}$-enriched seawater after $t 10$ were used to maintain $p \mathrm{CO}_{2}$ levels as close to target values as possible. Thus, the mainte-

\section{Negative effect of ocean acidification on diazotroph biomass not reflected in diazotroph activity}

During the period of highest Nostocales biomass $(t 3-t 10), \delta^{15} \mathrm{~N}-\mathrm{PN}$ decreased in all treatments. This may indicate increased uptake of isotopically light $\mathrm{N}$, potentially through fixation of low $\delta^{15} \mathrm{~N}$ from atmospheric $\mathrm{N}_{2}$ by diazotrophs, into plankton community biomass. Yet there is no direct evidence that $\delta^{15} \mathrm{~N}$ $\mathrm{PN}$, a proxy for diazotroph activity, was directly affected by $\mathrm{CO}_{2}$, despite the strong negative response to $\mathrm{CO}_{2}$ observed in Nostocales biomass (Tables 1 \& 2; see also discussion in previous section).

Temperature had a more significant influence on $\delta^{15} \mathrm{~N}-\mathrm{PN}$ than $\mathrm{CO}_{2}$, with warmer temperature having a negative effect on $\delta^{15} \mathrm{~N}-\mathrm{PN}$. This temperature effect on this potential diazotroph activity proxy could not be attributed to higher diazotroph biomass in the higher temperature treatment (Tables $1 \& 2$ ). Additional factors such as a high importance of regenerative production (Sigman et al. 2009), differential nitrate isotope fractionation between phytoplankton species (Needoba et al. 2003) and uncertainty in inorganic $\mathrm{N}$ concentration, also complicate interpretation of the potential diazotrophic $\delta^{15} \mathrm{~N}$ signature in $\delta^{15} \mathrm{~N}-\mathrm{PN}$. In this study, there were higher zooplankton abundances (C. Paul et al. 2016), and presumably also higher zooplankton organic matter respiration, in the warmer treatments. Inorganic $\mathrm{N}$ concentrations were below the detection limit, and therefore their influence on $\delta^{15} \mathrm{~N}-\mathrm{PN}$ was assumed to be negligible. Hence, increased regeneration of 
isotopically light inorganic nitrogen by zooplankton may better explain variation in $\delta^{15} \mathrm{~N}-\mathrm{PN}$ than diazotroph activity.

The response of other indicators of diazotroph activity, such as $\mathrm{P}^{*}$, to $\mathrm{CO}_{2}$ and temperature are also contradictory. For example, Nostocales biomass had a significant negative correlation with $\mathrm{P}^{*}$ during the bloom phase (Table 2), fitting with the idea from Deutsch et al. (2007) that diazotrophs add N, use P and thereby reduce $\mathrm{P}^{*}$. However, $\mathrm{P}^{*}$ was also negatively correlated with both $\mathrm{CO}_{2}$ and temperature independently during the bloom phase (Table 2). This would suggest higher $\mathrm{N}_{2}$-fixation under higher $\mathrm{CO}_{2}$ and higher temperature, thus contradicting the negative relationship detected between Nostocales biomass and $\mathrm{CO}_{2}$ and $\mathrm{CO}_{2} \times$ temperature (Table 1). These opposing responses indicate that Nostocales were not shaping the response of $\mathrm{P}^{*}$ to $\mathrm{CO}_{2}$ and temperature. Reasons for this could be their low contribution of diazotrophic cyanobacteria to plankton biomass, or the nutrient uptake of other more abundant, non-diazotrophic plankton. Thus, while diazotroph biomass was significantly affected by elevated $\mathrm{CO}_{2}$, we have no clear indication of any temperature or $\mathrm{CO}_{2}$ effect on diazotroph activity within this $28 \mathrm{~d}$ long study period.

\section{Potential consequences for future diazotrophic N supply to the Baltic Sea}

Despite warm temperatures $\left(>16^{\circ} \mathrm{C}\right)$, light and phosphate availability fitting the suggested requirements for diazotrophic growth in the Baltic Sea (Wasmund 1997), no large bloom of Nostocales developed in our study. Nostocales generally contributed to less than $1 \%$ of total phytoplankton biomass (Fig. 2C,D). This is considerably less than in field studies reporting large surface aggregates contributing around 20 to $30 \%$ of plankton community biomass (Stal et al. 1999, Andersson et al. 2015); consequently, their influence on biogeochemical pools was limited. The lack of bloom development could also be due to experimental artefacts. In order to control temperature, this study took place indoors, where we mimicked natural light conditions using an artificial light source with no UV radiation. Lack of UV radiation can influence phytoplankton community composition (Mousseau et al. 2000) and cell stoichiometry (Hessen et al. 2008), and can modulate the physiological response of phytoplankton to ocean acidification (Gao et al. 2009). Additionally, the well-mixed mesocosms may have provided less favourable conditions for $N$. spumigena, which usually bloom in highly stratified water columns (Wasmund 1997).

The negative growth response of the dominant diazotrophic cyanobacterium in this study, N. spumigena, to increasing $\mathrm{CO}_{2}$ reported in some physiological studies was verified here in a natural plankton community. The direction of the negative physiological $\mathrm{CO}_{2}$ response in this Baltic Sea cyanobacterium was not modified through resource competition with other phytoplankton functional groups or by topdown grazing pressure. If this negative $\mathrm{CO}_{2}$ effect on biomass cascades through the food web over longer time periods, it may lead to a decrease in diazotroph $\mathrm{N}$ inputs, with consequences for productivity in the wider plankton community.

Acknowledgements. We thank all participants of the indoor mesocosm study, in particular Jessica Garzke for experiment co-ordination, logistics and assistance with $\mathrm{CO}_{2}$ manipulations. We also thank Roberto Benavides, Bente Gardeler, Laura Gobelius, Thomas Hansen, Dana Hellemann, Henriette Horn, Andrea Ludwig and Kerstin Nachtigall for assistance in mesocosm set-up, sampling and analyses. Thanks also to Lennart Bach, Sonja Endres, Scarlett Sett and Arvind Singh for helpful discussions while preparing this manuscript, and to 2 anonymous reviewers for their constructive comments. This study was funded by the Cluster of Excellence 'The Future Ocean' (Project CP1141) and the German Federal Ministry of Education and Research (BMBF) programme BIOACID II (FKZ 03F06550).

\section{LITERATURE CITED}

Alsterberg C, Eklöf JS, Gamfeldt L, Havenhand JN, Sundbäck K (2013) Consumers mediate the effects of experimental ocean acidification and warming on primary producers. Proc Natl Acad Sci USA 110:8603-8608

Andersson A, Höglander H, Karlsson C, Huseby S (2015) Key role of phosphorus and nitrogen in regulating cyanobacterial community composition in the northern Baltic Sea. Estuar Coast Shelf Sci 164:161-171

Barcelos e Ramos J, Biswas H, Schulz KG, LaRoche J, Riebesell U (2007) Effect of rising atmospheric carbon dioxide on the marine nitrogen fixer Trichodesmium. Global Biogeochem Cycles 21:GB2028

Behrends G (1997) Long-term investigation of seasonal mesozooplankton dynamics in Kiel Bight, Germany. Proceedings of the 13th Baltic Marine Biologists Symposium, Jurmala, Latvia, August 31-September 4, 1993. Institute of Aquatic Ecology, University of Latvia, Riga, p 93-98

Böttjer D, Karl DM, Letelier RM, Viviani DA, Church MJ (2014) Experimental assessment of diazotroph responses to elevated seawater $p \mathrm{CO}_{2}$ in the North Pacific Subtropical Gyre. Global Biogeochem Cycles 28:601-616

* Breitbarth E, Oschlies A, LaRoche J (2007) Physiological constraints on the global distribution of Trichodesmium-effect of temperature on diazotrophy. Biogeosciences 4:53-61

Brewer PG (1997) Ocean chemistry of the fossil fuel $\mathrm{CO}_{2}$ 
signal: the haline signal of 'business as usual'. Geophys Res Lett 24:1367-1369

Brock TD (1981) Calculating solar radiation for ecological studies. Ecol Model 14:1-19

Coello-Camba A, Agustí S, Holding J, Arrieta JM, Duarte $\mathrm{CM}$ (2014) Interactive effect of temperature and $\mathrm{CO}_{2}$ increase in Arctic phytoplankton. Front Mar Sci 1:49

Collins M, Knutti R, Arblaster J, Dufresne JL and others (2013) Long-term climate change: projections, commitments and irreversibility. In: Stocker TF, Qin D, Plattner GK, Tignor M and others (eds) Climate change 2013: the physical science basis. Contribution of Working Group I to the Fifth Assessment Report of the Intergovernmental Panel on Climate Change. Cambridge University Press, Cambridge, p 1029-1136

Czerny J, Ramos J, Riebesell U (2009) Influence of elevated $\mathrm{CO}_{2}$ concentrations on cell division and nitrogen fixation rates in the bloom-forming cyanobacterium Nodularia spumigena. Biogeosciences 6:1865-1875

* Dabundo R, Lehmann MF, Treibergs L, Tobias CR, Altabet MA, Moisander PH, Granger J (2014) The contamination of commercial ${ }^{15} \mathrm{~N}_{2}$ gas stocks with ${ }^{15} \mathrm{~N}$-labeled nitrate and ammonium and consequences for nitrogen fixation measurements. PLOS ONE 9:e110335

* Deutsch C, Sarmiento JL, Sigman DM, Gruber N, Dunne JP (2007) Spatial coupling of nitrogen inputs and losses in the ocean. Nature 445:163-167

Dickson AG, Sabine CL, Christian JR (eds) (2007) Guide to best practices for ocean $\mathrm{CO}_{2}$ measurements. PICES Special Publication 3, IOCCP Rep 8. North Pacific Marine Science Organization, Sidney

* Döös K, Meier HEM, Döscher R (2004) The Baltic haline conveyor belt or the overturning circulation and mixing in the Baltic. Ambio 33:261-266

* Eichner M, Rost B, Kranz SA (2014) Diversity of ocean acidification effects on marine $\mathrm{N}_{2}$ fixers. J Exp Mar Biol Ecol 457:199-207

Engel A, Schulz KG, Riebesell U, Bellerby R, Delille B, Schartau M (2008) Effects of $\mathrm{CO}_{2}$ on particle size distribution and phytoplankton abundance during a mesocosm bloom experiment (PeECE II). Biogeosciences 5: $509-521$

Engström-Öst J, Viitasalo M, Jónasdóttir S, Repka S, Sivonen K, Koski M, Schmidt K (2002) Calanoid copepods feed and produce eggs in the presence of toxic cyanobacteria Nodularia spumigena. Limnol Oceanogr 47: 878-885

Fu FX, Warner ME, Zhang YH, Feng YY, Hutchins DA (2007) Effects of increased temperature and $\mathrm{CO}_{2}$ on photosynthesis, growth, and elemental ratios in marine Synechococcus and Prochlorococcus (Cyanobacteria). J Phycol 43:485-496

Fu FX, Yu E, Garcia NS, Gale J, Luo Y, Webb EA, Hutchins DA (2014) Differing responses of marine $\mathrm{N}_{2}$ fixers to warming and consequences for future diazotroph community structure. Aquat Microb Ecol 72:33-46

Gao K, Ruan Z, Villafañe VE, Gattuso JP, Helbling EW (2009) Ocean acidification exacerbates the effect of UV radiation on the calcifying phytoplankter Emiliania huxleyi. Limnol Oceanogr 54:1855-1862

* Gradoville MR, White AE, Letelier RM (2014) Physiological response of Crocosphaera watsonii to enhanced and fluctuating carbon dioxide conditions. PLOS ONE 9: e110660

*Gustafsson Ö, Gelting J, Andersson P, Larsson U, Roos P
(2013) An assessment of upper ocean carbon and nitrogen export fluxes on the boreal continental shelf: a 3-year study in the open Baltic Sea comparing sediment traps, ${ }^{234}$ Th proxy, nutrient, and oxygen budgets. Limnol Oceanogr Methods 11:495-510

Hansen HP, Koroleff F (1999) Determination of nutrients. In: Grasshoff K, Kremling K, Ehrhardt M (eds) Methods of seawater analysis. Wiley Verlag Chemie, Weinheim, p 159-228

*Hare CE, Leblanc K, DiTullio GR, Kudela RM and others (2007) Consequences of increased temperature and $\mathrm{CO}_{2}$ for phytoplankton community structure in the Bering Sea. Mar Ecol Prog Ser 352:9-16

HELCOM (Helsinki Commission) (2013) Climate change in the Baltic Sea Area: HELCOM thematic assessment in 2013. HELCOM, Helsinki

* Hessen DO, Leu E, Færøvig PJ, Falk Petersen S (2008) Light and spectral properties as determinants of C:N:P-ratios in phytoplankton. Deep Sea Res II 55:2169-2175

*Hillebrand H, Dürselen CD, Kirschtel D, Pollingher U, Zohary T (1999) Biovolume calculation for pelagic and benthic microalgae. J Phycol 35:403-424

* Hübel H, Hübel M (1974) Stickstoff-Fixierung in Küstengewässern der mittleren Ostsee. Z Allg Mikrobiol 14: $617-619$

Huber A (1986) Nitrogen-fixation by Nodularia spumigena Mertens (Cyanobacteriaceae). 2. Laboratory Studies. Hydrobiologia 133:193-202

*Hutchins DA, Fu FX, Webb EA, Walworth N, Tagliabue A (2013) Taxon-specific response of marine nitrogen fixers to elevated carbon dioxide concentrations. Nat Geosci 6: 790-795

Hutchins DA, Walworth NG, Webb EA, Saito MA and others (2015) Irreversibly increased nitrogen fixation in Trichodesmium experimentally adapted to elevated carbon dioxide. Nat Commun 6:8155

KKononen K, Kuparinen J, Mäkelä K, Laanemets J, Pavelson J, Nõmmann S (1996) Initiation of cyanobacterial blooms in a frontal region at the entrance to the Gulf of Finland, Baltic Sea. Limnol Oceanogr 41:98-112

Kaw CS, Breitbarth E, Hoffmann LJ, McGraw CM and others (2012) No stimulation of nitrogen fixation by nonfilamentous diazotrophs under elevated $\mathrm{CO}_{2}$ in the South Pacific. Glob Change Biol 18:3004-3014

Lehtimaki J, Sivonen K, Luukkainen R, Niemela SI (1994) The effects of incubation time, temperature, light, salinity, and phosphorus on growth and hepatotoxin production by Nodularia strains. Arch Hydrobiol 130: 269-282

KLehtimaki J, Moisander P, Sivonen K, Kononen K (1997) Growth, nitrogen fixation, and nodularin production by two Baltic Sea cyanobacteria. Appl Environ Microbiol 63: 1647-1656

KLindstrom ML, Bates DM (1990) Nonlinear mixed effects models for repeated measures data. Biometrics 46: 673-687

Maugendre L, Gattuso JP, Louis J, de Kluijver A, Marro S, Soetaert K, Gazeau F (2015) Effect of ocean warming and acidification on a plankton community in the NW Mediterranean Sea. ICES J Mar Sci 72:1744-1755

Menden-Deuer S, Lessard EJ (2000) Carbon to volume relationships for dinoflagellates, diatoms, and other protist plankton. Limnol Oceanogr 45:569-579

* Millero FJ, Graham TB, Huang F, Bustos-Serrano H, Pierrot D (2006) Dissociation constants of carbonic acid in sea- 
water as a function of salinity and temperature. Mar Chem 100:80-94

Mohr W, Grosskopf T, Wallace DWR, LaRoche J (2010) Methodological underestimation of oceanic nitrogen fixation rates. PLOS ONE 5:e12583

Mousseau L, Gosselin M, Levasseur M, Demers S and others (2000) Effects of ultraviolet B radiation on simultaneous carbon and nitrogen transport rates by estuarine phytoplankton during a week-long mesocosm study. Mar Ecol Prog Ser 199:69-81

Needoba JA, Waser NA, Harrison PJ, Calvert SE (2003) Nitrogen isotope fractionation in 12 species of marine phytoplankton during growth on nitrate. Mar Ecol Prog Ser 255:81-91

Olenina I, Hajdu S, Edler L, Andersson A and others (2006) Biovolumes and size-classes of phytoplankton in the Baltic Sea. HELCOM Balt Sea Environ Proc No 106. Helsinki Commission, Baltic Marine Environment Protection Commission, Helsinki

Omstedt A, Edman M, Claremar B, Frodin P and others (2012) Future changes in the Baltic Sea acid-base (pH) and oxygen balances. Tellus B Chem Phys Meterol 64:1

Paerl HW (2012) Marine plankton. In: Whitton BA (ed) Ecology of Cyanobacteria II: their diversity in space and time. Springer Science \& Business Media, Dordrecht, p 134

Paerl HW, Huisman J (2008) Blooms like it hot. Science 320: 57-58

Paul AJ, Achterberg EP, Bach LT, Boxhammer T and others (2016) No observed effect of ocean acidification on nitrogen biogeochemistry in a summer Baltic Sea plankton community. Biogeosciences 13:3901-3913

Paul C, Sommer U, Garzke J, Moustaka-Gouni M, Paul AJ, Matthiessen B (2016) Effects of increased $\mathrm{CO}_{2}$ concentrations on nutrient limited coastal summer plankton depend on temperature. Limnol Oceanogr 61:853-868

Pierrot DE, Wallace DWR, Lewis E (2011) MS Excel program developed for $\mathrm{CO}_{2}$ system calculations. RNL/CDIAC105a. Carbon Dioxide Information Analysis Center, Oak Ridge National Laboratory, US Department of Energy, Oak Ridge, TN

Pinheiro J, Bates D, DebRoy S, Sakar D, R Core Team (2015) nlme: Linear and Nonlinear Mixed Effects Models. R Package version 3.1-128. https://cran.r-project.org/src/ contrib/Archive/nlme/nlme_3.1-128.tar.gz

Pliński M, Jóźwiak T (1999) Temperature and N:P ratio as factors causing blooms of blue-green algae in the Gulf of Gdańsk. Oceanologia 41:73-80

Redfield AC (1958) The biological control of chemical factors in the environment. Am Sci 46:205-221

*Rees AP, Turk-Kubo KA, Al-Moosawi L, Alliouane S, Gazeau F, Hogan ME, Zehr JP (2017) Ocean acidification impacts on nitrogen fixation in the coastal western Mediterranean Sea. Estuar Coast Shelf Sci 186:45-57

Sanz-Alférez S, del Campo FF (1994) Relationship between nitrogen fixation and nitrate metabolism in the Nodularia strains M1 and M2. Planta 194:339-345

Schneider B, Eilola K, Lukkari K, Muller-Karulis B, Neumann T (2015) Environmental impacts - marine biogeochemistry. In: The BACC II Author Team (ed) Second assessment of climate change for the Baltic Sea basin. Springer International Publishing, p 337-361

Schulz KG, Bellerby RGJ, Brussaard CPD, Büdenbender J and others (2013) Temporal biomass dynamics of an Arc- tic plankton bloom in response to increasing levels of atmospheric carbon dioxide. Biogeosciences 10:161-180

Sharp J (1974) Improved analysis for particulate organic carbon and nitrogen from seawater. Limnol Oceanogr 19: 984-989

Sigman DM, Karsh KL, Casciotti KL (2009) Ocean process tracers: nitrogen isotopes in the ocean. In: Steele J, Thorpe S, Turekian K (eds) Encyclopedia of ocean sciences. Academic Press, Elsevier, New York, NY, p 40-54

Smetacek V (1985) The annual cycle of Kiel Bight plankton: a long-term analysis. Estuaries 8:145-157

* Sommer U, Lengfellner K, Lewandowska A (2012) Experimental induction of a coastal spring bloom early in the year by intermittent high-light episodes. Mar Ecol Prog Ser 446:61-71

* Sommer U, Paul C, Moustaka-Gouni M (2015) Warming and ocean acidification effects on phytoplankton - from species shifts to size shifts within species in a mesocosm experiment. PLOS ONE 10:e0125239

Staal M, Meysman FJR, Stal LJ (2003) Temperature excludes $\mathrm{N}_{2}$-fixing heterocystous cyanobacteria in the tropical oceans. Nature 425:504-507

* Stal LJ, Staal M, Villbrandt M (1999) Nutrient control of cyanobacterial blooms in the Baltic Sea. Aquat Microb Ecol 18:165-173

Suikkanen S, Pulina S, Engström-Öst J, Lehtiniemi M, Lehtinen S, Brutemark A (2013) Climate change and eutrophication induced shifts in northern summer plankton communities. PLOS ONE 8:e66475

Sweitzer J, Langaas S, Folke C (1996) Land cover and population density in the Baltic Sea drainage basin: a GIS database. Ambio 25:191-198

* Thomsen J, Gutowska MA, Saphörster J, Heinemann A and others (2010) Calcifying invertebrates succeed in a naturally $\mathrm{CO}_{2}$-rich coastal habitat but are threatened by high levels of future acidification. Biogeosciences 7 : 3879-3891

Utermöhl H (1958) Zur Vervollkommnung der quantitativen Phytoplankton-Methodik. Mitt Int Ver Theor Angew Limnol 9:1-38

*Vahtera E, Conley DJ, Gustafsson BG, Kuosa H and others (2007) Internal ecosystem feedbacks enhance nitrogenfixing cyanobacteria blooms and complicate management in the Baltic Sea. Ambio 36:186-194

Vintila S, El-Shehawy R (2010) Variability in the response of the cyanobacterium Nodularia spumigena to nitrogen supplementation. J Environ Monit 12:1885-1890

von Storch H, Omstedt A, Pawlak J, Reckermann M (2015) Introduction and summary. In: The BACC II Author Team (ed) Second assessment of climate change for the Baltic Sea Basin. Springer International Publishing, p 1-22

Wannicke N, Endres S, Engel A, Grossart HP, Nausch M, Unger J, Voss M (2012) Response of Nodularia spumigena to $p \mathrm{CO}_{2}$. I. Growth, production and nitrogen cycling. Biogeosciences 9:2973-2988

Wasmund N (1997) Occurrence of cyanobacterial blooms in the Baltic Sea in relation to environmental conditions. Int Rev Gesamten Hydrobiol 82:169-184

Wasmund N, Göbel J, von Bodungen B (2008) 100-yearschanges in the phytoplankton community of Kiel Bight (Baltic Sea). J Mar Syst 73:300-322

Submitted: October 9, 2017; Accepted: May 8, 2018

Proofs received from author(s): June 12, 2018 